\section{Re: Autoimmun myopati ved statinbruk}

Ljøstad \& Mygland beskriver i Tidsskriftet nr. 16/2016 en heldigvis sjelden bivirkning ved statinbehandling (1). Patogenesen antas å involvere autoimmunitet, og det er derfor naturlig å gripe til immunsuppressiv behandling i tillegg til å seponere statinet.

De tre pasientene fikk ulike kombinasjoner av immunsuppressiva, men alle fikk på ett eller flere tidspunkter intravenøst gammaglobulin (IvIg). De to første pasientene synes å ha oppnådd en stabil remisjon, mens den tredje etter fire år fortsatt er svak i hofte og skuldre.

Det finnes ingen kliniske studier som tilsier at IvIg har effekt ved denne tilstanden. Noe annet enn en hypotese om at det immunmodulerende IvIg vil kunne påvirke den antatte autoimmune reaksjonen på gunstig vis, finnes heller ikke. Ut fra forfatternes observasjoner er det heller ikke mulig å si noe om IvIg har hatt effekt eller om det hadde vært like bra eller bedre å basere seg utelukkende på ikke-humanbaserte immunsuppressiva. På den annen side: en gunstig effekt av IvIg kan ikke utelukkes (2).

Det er grunn til å minne om at IvIg produseres fra humant plasma, altså fra råvare gitt av blodgivere, og at Norge har et betydelig underskudd på plasma til fremstilling av IvIg (3). Forbruket har økt sterkt siden årtusenskiftet. Fra 2008 har Norge ikke produsert nok plasma til å dekke forbruket, og dette dekkes i dag fra plasma fra betalte plasmagivere i Mellom-Europa. Dette er i seg selv et etisk problem, som forsterkes ved at evidensgrunnlaget for bruk av IvIg generelt er svakt (4). Det finnes heller ingen data som kan veilede om hva som er optimalt behandlingsopplegg ved denne tilstanden, og det er karakteristisk at de tre pasientene fikk IvIg etter ulike opplegg.

Det er også grunn til å minne om at IvIg koster ca. kr 600 per gram. Gitt at pasient 1 og 3 veide $60 \mathrm{~kg}$ hver og pasient 2 veide $70 \mathrm{~kg}$, er utgiftene til IvIg som beskrevet i figur 3, kr 72000 for pasient 1, kr 504000 for pasient 2 og kr 216000 for pasient 3. Ut fra de data om gis i figur 3, er det vanskelig å avgjøre om dette ressursforbruket har gitt positiv effekt for noen av pasientene.

IvIg er et preparat hvis bruk bør gjennomtenkes nøye av så vel etiske som økonomiske grunner. Ljøstad \& Myglands artikkel ville ha vært styrket hvis forfatterne hadde gått dypere inn i behandlingsproblematikken og bl.a. påpekt de særlige problemene som knytter seg til bruk av IvIg. Det er sterkt ønskelig at disse problemene også overveies ved bruk av IvIg i andre kliniske situasjoner (3).

\section{Hans Erik Heier}

heheier@online.no

Hans Erik Heier (f. 1944) er professor emeritus ved Universitetet i Oslo. Ingen oppgitte interessekonflikter

\section{Litteratur}

1. Ljøstad U, Mygland $\AA$. Autoimmun myopati ved statinbruk. Tidsskr Nor Lege foren 2016; 136: 1360-2

2. Mammen AL. Statin-associated autoimmune myopathy. N Engl J Med 2016; 374: 664-9.

3. Heier HE, Svenningsen V, Olaussen RW. Går det mot blodforsyningskrise i Norge? Tidsskr Nor Legeforen 2012; 132: 2508-10

4. Kornør H, Hammerstrøm KT. Brurberg KG et al. Immunmodulerende behand ling med intravenøst gammaglobulin. Rapport nr. 14-2008. Oslo: Kunnskapssenteret, 2008.
Vi har her å gjere med epigenetiske effekter over generasjonane. I placenta og lungevev frå foster frå røykande mødre er det påvist epigenetiske endringar som var spesielt hyppige i gen som hadde relasjon til astma og immunsystemet (5).

I ein eksperimentell studie førte perinatal nikotineksponering til astma ikkje berre hos avkommet, men også hos F2-generasjonen, altså hos «barnebarna» til dei nikotin-eksponerte dyra $(6,7)$. Effektene av nikotin på lungeutviklinga hos ulike dyreartar (mus, rotte, sau, ape) er svært like, og verknaden på mennesket er neppe annleis (3). Dei molekylære mekanismane for at nikotin fører til astma er kjende (8-10). Dette aukar sannsynlegheita for at nikotin i fosterlivet kan føre til astma også hos menneskebarn. Dette blir understreka i to nylege kommentarartiklar i førande tidsskrift $(3,10)$.

Nikotineksponering i svangerskapet kan med stor sannsynlegheit vere årsak til astma hos kommande generasjonar. Gravide bør derfor unngå alle former for nikotintilførsel, også snus.

\section{Martinus Løvik}

martloev@online.no

Martinus Løvik (f. 1943) er professor emeritus ved Institutt for kreftforskning og molekylærmedisin, Norges teknisk-naturvitenskapelige universitet.

Ingen oppgitte interessekonflikter.

\section{Litteratur}

1. Rygh E, Gallefoss F, Reiso H. Bruk av snus og røyketobakk hos gravide i Agder Tidsskr Nor Legeforen 2016; 136: 1351-4.

2. Jacobsen GW. Bør gravide avstå fra enhver bruk av nikotin? Tidsskr Nor Legeforen 2016; 136: 1320

3. Spindel ER, McEvoy CT. The Role of nicotine in the effects of maternal smoking during pregnancy on lung development and childhood respiratory disease. Implications for dangers of e-cigarettes. Am J Respir Crit Care Med 2016; 193: $486-94$

4. Li YF, Langholz B, Salam MT et al. Maternal and grandmaternal smoking patterns are associated with early childhood asthma. Chest 2005; 127: 1232-41.

5. Chhabra D, Sharma S, Kho AT et al. Fetal lung and placental methylation is associated with in utero nicotine exposure. Epigenetics 2014: 9: 1473-84.

6. Rehan VK, Liu J, Naeem E et al. Perinatal nicotine exposure induces asthma in second generation offspring. BMC Med 2012; 10: 129

7. Leslie FM. Multigenerational epigenetic effects of nicotine on lung function. BMC Med 2013: 11: 27

8. Liu J, Sakurai R, Rehan VK. PPAR-? agonist rosiglitazone reverses perinatal nicotine exposure-induced asthma in rat offspring. Am J Physiol Lung Cell Mol Physiol 2015; 308: L788-96.

9. Gibbs K, Collaco JM, McGrath-Morrow SA. Impact of tobacco smoke and nicotine exposure on lung development. Chest 2016; 149: 552-61.

10. Spindel ER, McEvoy CT. Reply: Why pregnant women should avoid any form of nicotine during pregnancy: An elastin-based erspective. Am J Respir Crit Care Med 2016; 194: 247-8.

\section{RETTELSER}

\section{En syv måneder gammel jente med svette føtter}

Ann Christin Gjerstad, Olav Trond Storrøsten, Egil Bakkeheim, Kai Handeland, Hans-Jacob Bangstad

Tidsskr Nor Legeforen 2016; 136: 1366

Riktig navn på en av forfatterne skal være Egil Bakkeheim.

Vi beklager feilen. Den er rettet på nett.

God startbok i kognitiv terapi

Per Vaglum

Tidsskr Nor Legeforen 2016; 136: 1470

Riktig navn i følgende setning skal være:

Det var nettopp gjennom observasjoner av depressive pasienter i psykoanalyse, at grunnleggeren av kognitiv psykoterapi, Aaron Beck, oppdaget at et bestemt tankemønster kunne vedlikeholde en depresjon hos enkelte pasienter.

Vi beklager feilen. Den er rettet på nett. 